\title{
Patterns of Hospitality: \\ Aspects of Institutionalisation in 15th \& 16th \\ Centuries Nuremberg Healthcare
}

\author{
Fritz Dross
}

\section{Introduction}

$\mathrm{B}$ eginning in the late $14^{\text {th }}$ and accelerating in the mid- $15^{\text {th }}$ century, health care relief underwent far-reaching changes in German imperial cities.' With regard to the organisational framework of relief they have been analysed and described as processes of institutionalisation, hospitalisation, specialisation, and communalisation. With respect to the healing personnel in charge of applying health care relief schemes initiated by the city councils and hospital administrations, this development has been characterised as professionalisation. ${ }^{2}$ Altogether, these transformations could be looked at as a premodern stage of "medicalisation". But of course, one risks anachronism when applying this term to earlier developments. ${ }^{3}$

This paper concentrates on institutional welfare ${ }^{4}$ provided by hospitals and aims to give a concise overview of the developments in the imperial city of Nuremberg in southern Germany. Information available on each individual institution is relatively

1 Robert Jütte, Obrigkeitliche Armenfürsorge in deutschen Reichsstädten der frühen Neuzeit. Städtisches Armenwesen in Frankfurt am Main und Köln (Cologne 1984); Annemarie Kinzelbach, Gesundbleiben, Krankwerden, Armsein in der frühneuzeitlichen Gesellschaft : Gesunde und Kranke in den Reichsstädten Überlingen und Ulm, 1500-1700 (Stuttgart 1995); Annemarie Kinzelbach: "Infection, Contagion, and Public Health in Late Medieval and Early Modern German Imperial Towns", Journal of the History of Medicine and Allied Sciences 61 (2006), p. 369-389.

2 As general overview see Martin Dinges: "A History of Poverty and Poor Relief: Contributions from Research on the Early Modern Period and the Late Middle Ages and Examples from More Recent History", in Laurinda Abreu ed., European health and social welfare policies, [Santiago de Compostela] (2004), p. 23-50.

3 Cf. John Henderson: "Medizin für den Körper und Medizin für die Seele - Hospitäler im Florenz der Renaissance", in Michael Matheus ed., Funktions- und Strukturwandel spätmittelalterlicher Hospitäler im europäischen Vergleich (Stuttgart 2005), p. 33.

4 Concerning the concept of "institution" and "institutional welfare" see Martin Dinges: Introduction to the Volume: Situating Health Care: An Historical Perspective, in: Hygiea Internationalis 5 (2006), p. 7-13; Fritz Dross: "The Invention of a Medical Institution? A Discussion of Hospitals around 1800", in: Hygiea Internationalis 5 (2006), p. 91-106. 
poor and mostly extracted from the historical literature. The primary goal of this paper is thus not to enlarge our knowledge of particular Nuremberg relief institutions but to deepen our understanding of their interplay.

As an "imperial city", Nuremberg was directly subordinated to the Emperor and not - like for instance Berlin, Munich or Vienna - to one of the authorities of a territory. As the Emperor's residence was distant, the authorities of the imperial cities were especially powerful and can be presented as forerunners of modernisation in nearly every respect of public administration. Thus, "imperial city" is a juridical concept characterising the status of a particular city within the Holy Roman Empire; it does not mean "big town" at all -most of them were small in size but conserved the same legal status within the framework of the Empire. Nuremberg was one of a handful of large imperial cities in the $15^{\text {th }}$ and $16^{\text {th }}$ centuries. With some 36.000 inhabitants around 1500, Nuremberg was the second largest city in the Holy Roman Empire in that period, following Cologne (45.000), but bigger than Lübeck (24.000), Regensburg (22.000), Strasbourg (20.000), and Augsburg $(30.000){ }^{5}$

\section{Till Eulenspiegel in Nuremberg}

Till Eulenspiegel is a very popular figure of $16^{\text {th }}$ century folkloristic literature not only in the German-speaking part of Europe. The book ("Ein kurtzweilig lesen von Dyl Ulenspiegel geboren $u ß$ dem land zu Brunßwick. Wie er sein leben volbracht hatt. xcvi seiner geschichten.") ${ }^{6}$ tells the story of a prankster and trickster named Till Eulenspiegel (engl. "Master Tyll Owlglass") in 95 episodes. $^{7}$ The book is structured by the course of life of Eulenspiegel, beginning with his birth and ending with his death. The story takes place in northern Germany. The fool Eulenspiegel plays jokes on his contemporaries and tricks mainly craftsmen, but also noblemen and clergymen. The stories of Eulenspiegel are mentioned for the first time in letters exchanged by two German clerks of the papal court in Bologna and Padua,

5 Ulrich Rosseaux: Städte in der Frühen Neuzeit (Darmstadt 2006), pp. 9-11; Augsburg: Wolfram Baer, "Einwohnerzahlen", in G. Grünsteudel, ed, Augsburger Stadtlexikon, Augsburg 2nd ed. 1998 <http://www.augsburger-stadtlexikon.de/index.php> 15/07/2010. Of course, one has to be cautious with this numbers with regard to the sources and the difficult procedures in demographic research concerning the early modern period.

6 Wolfgang Lindow, ed., Ein kurtzweilig Lesen von Dil Ulenspiegel, geboren uß dem Land zu Brunßwick. Wie er sein Leben volbracht hatt. 96 seiner Geschichten. Nach dem Druck von 1515 (Stuttgart 1978). The authorship is dubious. The quoted edition is accessible via internet at $<$ http://www.zeno.org/Literatur/M/Bote, + Hermann/Schwanksammlung/Dil+Ulenspiegel> $15 / 07 / 2010$

7 The 42 nd of the 96 episodes is missing already in the 1515 edition. 
Dietrich von Niem und Johannes Schele in $1411 .^{8}$ In a chronicle written by Hermann Bote between 1493 and 1502 the author mentioned the death of „Ulenspeygel" in Mölln (between Hamburg and Lübeck) in the course of the great epidemic in 1350. ${ }^{9}$ The folkloristic stories were printed for the first time in Strasbourg $1510 / 11$ and at least 22 more German-speaking editions were printed in the $16^{\text {th }}$ century. Assuredly, more editions and several translations in other European languages were printed, ${ }^{10}$ and a countless number of adaptations, quotations and imitations made Eulenspiegel proverbial already in $16^{\text {th }}$ century.

The book was written in Northern Germany (Brunswick/Hanover area) where most of the stories took place. One time (Historie 17) ${ }^{11}$ Eulenspiegel also came to Nuremberg, announcing to be a great doctor. ${ }^{12}$ The hospital administrator immediately called for him and asked him to cure as many as possible of his 200 inmates. Eulenspiegel promised to enable them to leave their beds for $200 \mathrm{fl}$., and the hospital master accepted. Eulenspiegel talked to every single inmate telling everyone, that he could cure all of them but one whom he would have to burn in favour of preparing the medicine healing the others. Thus he proposed to choose the patient who was closest to death. Next morning he came to the hospital and cried out that every one who felt healthy should leave the hospital. Every one fled the hospital as fast and as far as she or he could - among these also people, who had not been able to leave their beds for weeks. Eulenspiegel took the money for his "cure" and left Nuremberg. Predictably, all former inmates came back in the following days.

8 Reinhard Tenberg, Die deutsche Till-Eulenspiegel-Rezeption bis zum Ende des 16. Jahrhunderts (Würzburg 1996), pp. 30-37.

9 Tenberg, Till-Eulenspiegel-Rezeption, p. 38.

10 E.g: Dutch: "Tijl Uilenspiegel", Polish: "Dyl Sowizdrzał", French: "Till l'espiègle" or "Ulespiègle", from where are derived an adjective "espiègle" (i.e. mischievous, roguish) and "espièglerie" (i.e. mischievousness, impishness, roguishness). Eulenspiegel did not enter English literature before 19th century; English translation: Kenneth R. H. Mackenzie, Master Tyll Owlglass: His Marvellous Adventures and Rare Conceits (London 1859) <http://ufdcweb1.uflib.ufl.edu/ufdc/?b=UF00003232\&v=00001> 15/07/2010 (1860 edition). It seems like a new story of Eulenspiegel that today the oldest printed edition which passed on completely (Strasbourg 1515) resides in the British National Museum in London. See Julia Buchloh, Hans Baldung Grien und Dyl Ulenspiegel. Studien zu den Illustrationen und zur TextBild-Struktur des Straßburger Eulenspiegeldruckes S 1515 (Diss. phil. TU Berlin 2005) $<$ http://deposit.ddb.de/cgi-bin/dokserv?idn=976609576> 15/07/2010; Katharina Dücker, Literarische Bösewichte des (Spät)mittelalters und ihre mögliche Vorbildfunktion für das Eulenspiegelbuch. (Pro Gradu-Arbeit, Institut für Sprach- und Translationswissenschaften, Deutsche Sprache und Kultur, Universität Tampere 2007) < http://tutkielmat.uta.fi/ pdf/gradu01649.pdf $>15 / 07 / 2010$.

11 <http://www.zeno.org/Literatur/M/Bote, + Hermann/Schwanksammlung/Dil+Ulenspie gel/Die+17.+Histori> 15/07/2010.

12 See Dücker, Literarische Bösewichte, p. 11 english translation: < http://ufdcweb1.uflib .ufl.edu/ufdc/?m=hd54]\&i=56821> 15/07/2010. 
Of course, all the Eulenspiegel stories are fiction - there is no historical proof that a person called Eulenspiegel ever lived and entered Nuremberg. At the same time, nobody would have had found these stories funny, had they not been conceivable.

An effect of widespread reception of the Eulenspiegel stories in $16^{\text {th }}$ century must have been to make Nuremberg famous as a city with a huge hospital offering 200 beds and enshrining the holy relics of the Empire, which are mentioned in the story. Obviously the author had correct information on the size and the circumstances of the Nuremberg's hospital of the Holy Spirit, which is not mentioned by name. Furthermore, the inmates of the hospital are without doubt distinguished as sick people, which was common, or at least not a totally exceptional perception of people living in hospitals. ${ }^{13}$ Even more concrete, sickness is described as being an inability to get up and to move. ${ }^{14}$ Eulenspiegel whose jokes in general are based on taking common metaphorical expressions literally, tricks the hospital master by making the hospital inmates get out of bed and away from hospital without "curing" them. This means that hospital administration in $16^{\text {th }}$ century obviously took care of inmates by paying "professionals" to cure them. Apparently, if one is to believe the story, expertise in terms of academic studies or an apprenticeship as barber-surgeon was not necessary to be admitted as a career or as a healer. Unfortunately, to decide whether a person was able to keep his or her promise to cure was not easy to ascertain prior to the cure.

\section{Hospitals in Medieval Nuremberg}

The imperial city of Nuremberg developed its hospital system in medieval times. A quick appraisal of the establishment of Nuremberg hospitals in medieval times is necessary before analysing the transition to the patterns of the early modern era. The first hospital in town was founded in the first third of the $13^{\text {th }}$ century, manned by the Teutonic Order and dedicated to Saint Elisabeth of Hungary. Both the commandery of the Teutonic Order and their hospital were located just outside the

13 Already in 1340 the founder of the Nuremberg Hospital of the Holy Spirit, Konrad Groß, warned the hospital administration of selling hospital places to healthy people. Ulrich Knefelkamp: Das Heilig-Geist-Spital in Nürnberg vom 14-17. Jahrhundert. Geschichte, Struktur, Alltag (Nürnberg 1989), p. 192f.

14 Which seems to be a characterisation of English hospital inmates already in $12^{\text {th }}$ century, "tresdecim pauperes inbecilles et ita viribus attenuati ut vix aut numquam sine alterius adminiculo se valeant sustenare." Brigitte Resl: "Hospitals in Mediaeval England”, in M. Scheutz, A. Sommerlechner, H. Weigl, A. S. Weiß, eds., Europäisches Spitalwesen - Institutionelle Fürsorge in Mittelalter und Früher Neuzeit (Wien 2008), pp. 41-52, quotation p. 47; Ortrun Riha: "'krank und siech' Zur Geschichte des Krankheitsbegriffs", in A. Friedrich, F. Heinrich, C. Vanja, eds., Das Hospital am Beginn der Neuzeit. Soziale Reform in Hessen im Spiegel europäischer Kulturgeschichte (Petersberg 2004), pp. 191-201. 
medieval city wall. Hospital and commandery remained extra-territorial ground after the enlargement of the city in $14^{\text {th }}$ and $15^{\text {th }}$ centuries when the hospital was enclosed in a new city wall. After the Reformation (in Nuremberg 1522-1533) the hospital chapel of the hospital of Saint Elisabeth was the only church where catholic worship was perpetuated. As a consequence of not being tied to the city's authorities or to the town's inhabitants confession, the hospital hosting about 50 people since late $14^{\text {th }}$ century hardly was subject to the changes in urban health care relief in $15^{\text {th }}$ and $16^{\text {th }}$ centuries.

In 1339 the rich merchant Konrad Groß founded the hospital of the Holy Spirit, which became the central institution of the city's health care and poor relief system. Being one of the most important hospitals in medieval Germany whose records have been kept until today, the Nuremberg hospital of the Holy Spirit played an initial role in German historiography considering the social history of hospitals. ${ }^{15}$ The founding charter ${ }^{16}$ of the hospital was considered to be a prototype document of what has been called the "budget for the beyond". ${ }^{17}$

Considering the particular status of a hospital capable of hosting about 200 inmates and quadrupling its property within half a century after its foundation, ${ }^{18}$ one must not underestimate its function in hosting the relics of the Holy Roman Empire since 1423. Once a year in the second week after Easter the relics were presented to the public ("Heiltumsweisung"). On this occasion the city opened its gates to foreigners. To get an impression of the visiting crowd, one could mention that e.g. in 1487 the City Council had armed about 1,000 men to control the event. ${ }^{19}$ Whenever the Emperor came to the imperial city he came to the hospital chapel to look at the relics, including e.g. the crown of Charles the Great.

Being more than an adequate place for civic foundations with respect to the "budget for the beyond" aiming to save the founders and the founders family

15 Knefelkamp: Das Heilig-Geist-Spital in Nürnberg.

16 Georg Löhlein, "Die Gründungsurkunde des Nürnberger Heilig-Geistspitals von 1339” Mitteilungen des Vereins für die Geschichte der Stadt Nürnberg 52 (1963/64), 65-79.

17 Ulrich Knefelkamp, "Stadt und Spital im späten Mittelalter. Ein struktureller Überblick zu Bürgerspitälern süddeutscher Städte”, in P. Johanek, ed., Städtisches Gesundheitsund Fürsorgewesen vor 1800 (Köln 2000), pp. 19-40; Brigitte Pohl-Resl, Rechnen mit der Ewigkeit. Das Wiener Bürgerspital im Mittelalter (Wien 1996); Resl: Hospitals in Medieval England, p. 48

18 Michael Diefenbacher, Sechshundertfünfzig 650 Jahre Hospital zum Heiligen Geist in Nürnberg: 1339-1989 (Nürnberg 1989); Michael Diefenbacher, ed., Das älteste Urbar des Nürnberger Heilig-Geist-Spitals (Nürnberg 1991).

19 "Man hat aus den acht Viertln der Statt aus jedem sechtzig bewehrter Mann genumen, auch aus den erbarn jungen Gesellen ainhundertundzwaintzig pferdt zusammengebracht, Unruh und Auffruhr zu verhüeten, und sein dartzu alle Thürn und Thor wol besetzt worden, sein ab aintausent Man in der Rüstung gewest." Johannes Müllner: Die Annalen der Reichsstadt Nürnberg von 1623. Vol. III: 1470 bis 1544 (Nürnberg 2003), p. 83. 
members' soul and their public commemoration, ${ }^{20}$ the Nuremberg hospital of the Holy Spirit was a holy place within the imperial city and throughout the Holy Empire. Commemorative worship in the hospital and by the inmates closest to the relics of the Empire must have been highly desirable. As a consequence, the hospital went on collecting huge extra foundations and became the owner of around 700 farmyards covering the whole region in the $18^{\text {th }}$ century. Since $15^{\text {th }}$ century the hospital administration was under control of the town aldermen.

As the hospital of the Holy Spirit has monopolised social historian's attention, several other institutions have not been subject to deeper investigation regarding their position within urban poor relief and health care support in medieval and early modern times. Four of the town's leprosaria are relatively well known, they were founded consecutively in the $13^{\text {th }}$ and $14^{\text {th }}$ centuries. As usual they were located outside the city walls on the main roads connecting the imperial city with its commercial partners of Prague, Regensburg, Augsburg, and Frankfurt (Main). ${ }^{21}$ Two of them admitted women and the other two men, although there seem to have been changes in gender allocations in the $15^{\text {th }}$ and $16^{\text {th }}$ centuries. ${ }^{22}$

Generally leprosaria differ from more general hospitals, as only people suffering leprosy were entitled to be admitted. Furthermore every leprous person was obliged to enter a leprosarium. The combination of the idea of a hospital dedicated to one distinct disease with a mandatory isolation directive seems quite modern and the modern idea of isolation obviously is a successor of the medieval treatment of lepers in general. ${ }^{23}$ At the same time one should be cautious not to confuse both. Admission into one of the leprosaria was not free of charge as one finds elsewhere. Furthermore, the four leprosaria took different admission fees. ${ }^{24}$ They had cooperative

20 Dietrich W. Poeck, "Wohltat und Legitimation", P. Johanek, ed., Städtisches Gesundheits- und Fürsorgewesen vor 1800. p. 1-17; Carole Rawcliffe: "'A Word from Our Sponsor': Advertising the Patron in the Medieval Hospital", in J. Henderson, P. Horden, A. Pastore, eds., The Impact of Hospitals: 300-2000 (Oxford 2007), p. 167-194.

21 Christine Seidel, Die Siechköbel vor den Mauern Nürnbergs (MA-Thesis ErlangenNürnberg 1984); Georg Gerneth, Beitrag zur Geschichte der Lepra und Leproserien in der alten Reichsstadt Nürnberg und in Fürth (Diss. med. Erlangen 1949); Walter Steinmaier, St. Jobst: Das Aussätzigenspital am Empfangsweg des Kaisers. Herrscherkult und Siechenhaus, ein Beitrag zum Stadtausbau unter Karl IV. und zum Spitalwesen der freien Reichsstadt Nürnberg (Nürnberg 2006).

22 Ernst Mummenhoff, Die öffentliche Gesundheits- und Krankenpflege im alten Nürnberg (Nürnberg 1898, Reprint Neustadt/Aisch 1986), p. 89.

23 In an European perspective see: Luke E. Demaitre, Leprosy in premodern medicine. A malady of the whole body (Baltimore 2007); Carole Rawcliffe, Leprosy in Medieval England (Woodbridge 2006); Bruno Tabuteau: "Historical Research Developments on Leprosy in France and Western Europe", in B. S. Bowers ed., The medieval hospital and medical practice (Aldershot 2007), p. 41-58; Kay Peter Jankrift, "Hospitäler und Leprosorien im Nordwesten des mittelalterlichen Regnum Teutonicum unter besonderer Berücksichtigung rheinisch-westfälischer Städte”, in Scheutz et al., eds., Europäisches Spitalwesen (Wien, München 2008), p. 295-306.

24 Steinmaier, St. Jobst, p. 49. 
constitutions so that the inmates themselves elected their masters who actually could be dropped by the inmates; if the master and congregation of the respective leprosarium did not agree with the administrator appointed by the City Council, they were entitled to require the nomination of another person. ${ }^{25}$ At the same time, sometimes people left the leprosarium after several years because they became "clean"; we also know of people not suffering leprosy but living in leprosaria.

Statistics on inmates are only available sporadically for $16^{\text {th }}$ and $17^{\text {th }}$ centuries and change very much; adding the respective maximum number of inmates of each leprosarium results in a total of 80 inhabitants, which certainly never was achieved. ${ }^{26}$ One can assume that all the four leprosaria accommodated for about 40 men and women in $15^{\text {th }}$ and about 60 in $16^{\text {th }}$ century. The four leprosaria as well as the two hospitals already mentioned exclusively admitted Nuremberg citizens. On the other hand the respective paragraphs concerning the leprosaria usually allowed admitting foreigners for one or two nights. Accommodation and nourishment appear to have been slightly better than given in "ordinary" hospitals. Certainly, the standard was better than one could assume the average standard of living of the lower middleclasses. Foremost it was regularly and predictable which was perhaps a cardinal particularity in premodern times.

The inhabitants were allowed to enter the city in favour of begging only when complying to strictly determined schedules with respect to places, date and time. The officers of the communal authorities were instructed to strictly separate the ordinary beggars from the leprous. Any person detected as "unclean" lost her or his benefits in other charities within the city of Nuremberg and had to move to one of the four leprosaria. This is stated e.g. in the founding charter of an almshouse accommodating old craftsmen of $1388 .{ }^{27}$ Consequently, the accounts of persons accommodated in the two Nuremberg "houses of 12 brothers" (Zwölfbrüderhäuser) mention several "brothers" who had been found "unclean" after some years and finally died in one of the leprosaria. ${ }^{28}$

To host foreigners, the imperial city had two hospitals dedicated to pilgrims, both of them located outside the city wall at the moment of their foundation in the

25 Willi Rüger, Mittelalterliches Almosenwesen: Die Almosenordnungen der Reichsstadt Nürnberg (Nürnberg 1932), p. $22 \mathrm{f}$.

26 Mummenhoff, Die öffentliche Gesundheits- und Krankenpflege, p. 96-98; the main sources of the two almshouses are accessible via internet <http://www.nuernbergerhausbuecher.de/> 15/07/2010.

27 Georg Wolfgang Karl Lochner, "Die Sondersiechen in Nürnberg, ihr Almosen und ihre Schau”, in Deutsche Zeitschrift für die Staatsarzneikunde NF 17 (1861), Nr. IV, 177-252, p. 181 and $189 f$.

28 Like in England „a significant number of fifteenth-century almshouses ... instituted measures for the prompt removal of lepers and anyone else who posed a risk to health." Rawcliffe, Leprosy in Medieval England, p. 277. 
1350ies and 1360ies: St. Martha and Holy-Cross. ${ }^{29}$ Like the leprosaria they hosted foreigners for one or two nights unless age, tiredness, sickness or cold and rainy weather hindered the departure of the pilgrims. ${ }^{30}$ Holy-Cross had 40 beds all in all, including those of the personnel. Numbers of hosted foreigners changed between 850 and 1,600 in 1470 ies, between 1,100 and 2,300 in the $1480 \mathrm{ies},{ }^{31}$ so one can assume that most inmates only stayed there for one or two nights.

On this background, shortly after the foundation of the two pilgrim's hospitals, the City Council tried to restrict access to foreigners already in its first regulation concerning begging in $1370 .{ }^{32}$ This is the first German regulation committing beggars to wear badges passed out after examination by a special municipal officer. As it was impossible to hermetically close the city only foreigners who stayed longer than three days were forbidden to enter the city again for one year.

Within that framework the foundation for the foreign lepers ("Sondersiechenalmosen") prima facie seems remarkable. ${ }^{33}$ Beginning in 1394 the city opened its gates for three days in the Holy Week before Easter to give clerical attendance, food and shelter to foreign lepers. This meant to take temporary care of people, who should not have been admitted for two reasons: for being foreigners and for being leprous. Whereas foreign beggars should have been refused at the city's gates according to municipal ordinances, citizens, who had been diagnosed as "unclean" should have been set out to one of the city's leprosaria. Consequently, in 1401 the City Council forbade this charity, which is said to have accommodated six persons in its first year. But reacting to an epidemic in the Holy Week 1405 the town aldermen had been accused of having attracted God's anger by banning the charity for the foreign lepers. Even more remarkable is the fact that the municipal authorities conceded

29 Kurt Pilz, Die Evangelisch-Reformierte St.-Marthakirche und das Pilgrim-Spital St. Martha. Die reformierte Gemeinde in Nürnberg (Nürnberg 1979); Helmut Haller von Hallerstein, Ernst Eichhorn, Das Pilgrimspital zum Heiligen Kreuz vor Nürnberg. Geschichte und Kunstdenkmäler (Nürnberg 1969).

30 "Auch kainen bilgram lenger dan ain nacht zu beherbergen on erlaubnis des pflegers; es deucht sich dan ainer ain wenig swach sein oder regenweter wer", quoted at Haller von Hallerstein, Eichhorn, Das Pilgrimspital zum Heiligen Kreuz vor Nürnberg, p. 40; Pilz, Die Evangelisch-Reformierte St.-Marthakirche, p. 10.

31 Haller von Hallerstein, Eichhorn, Das Pilgrimspital zum Heiligen Kreuz vor Nürnberg, p. $42 / 43$.

32 Edited in Rüger, Mittelalterliches Almosenwesen, p. 68; for the Portuguese example see Laurinda Abreu: "Beggars, Vagrants and Romanies: Repression and Persecution in Portuguese Society (14th-18th Centuries)", in Hygiea Internationalis 6 (2007), p. 41-66.

33 Stadtarchiv Nürnberg (StAN) (Municipal Archive of Nuremberg) A 21-31 Sondersiechen-Stiftung St. Sebald auf dem Kirchhof; Johannes Müllner, Die Annalen der Reichsstadt Nürnberg von 1623, vol. II: 1351 bis 1469 (Nürnberg 1984), pp. 135-137. The division of care for the Nuremberg foreign lepers reflects the categories of "The wild and the tame" mentioned by Rawcliffe, Leprosy in Medieval England, p. 291. 
this accusation by readmitting the charity which - following the history of the charity written in 1462 - immediately stopped the epidemic. ${ }^{34}$

\section{Hospitals in Nuremberg Since mid-15th Century}

When discussing historical developments beginning in the second half of the $15^{\text {th }}$ century, one has to bear in mind that the base of doing so, the records, changed considerably in quantity and quality. ${ }^{35}$ At the same time, the properties, rents, and revenues of the hospitals grew enormously. Consequently, the efforts of financial management had to be refined. ${ }^{36}$ This is a well-known development of modern administration. Obviously, historians of this era are at risk to take for a dramatic change something that was simply not mentioned earlier, before interesting an administration producing records. The major change, thus, is the need for a modern administration to regulate whatever it meant to give an authoritative order which does not mean as an imperative that the things to get under authoritative regulation changed themselves. On the other hand, it should be mentioned that health affairs, at least their financial impact, came into the focus of the regulating authority.

This could be shown by means of the history of the charity dispensed to foreign lepers. The earliest documentation of the "Sondersiechenalmosen" dates back to 1462 , when the charity came under administration of the municipal authorities. ${ }^{37}$ First of all, the new administrator appointed by the City Council wrote down the history of the charity and listed its funds. Doing so he secured administrational power and produced the oldest source giving us information on what had happened since 1394 . What we know of the late medieval history of the charity of the foreign lepers is already an effect of administrational modernisation.

In the following pages I am going to explore the development of a Nuremberg hospital and relief scheme in late $15^{\text {th }}$ and $16^{\text {th }}$ centuries by starting with the foreign lepers' charity. Looking for a supposedly weak institution can contribute to draw a more reasonable picture than the describing further growth of the Holy Spirit, one of the biggest (and richest) hospitals of that era. At the same time, the aim of the charity to host and feed foreign lepers seems incompatible with the authoritative

34 "Als pald das geschah. da horet der sterb vnd der portzel auf." StAN A 21-31 Sondersiechen-Stiftung St. Sebald auf dem Kirchhof.

35 Kinzelbach: Infection, Contagion and Public Health, pp. 379-381.

36 As Italian examples see: Matthew Thomas Sneider: "The Treasury of the Poor: Hospital Finance in Sixteenth and Eighteenth Century Bologna", in Henderson et al., eds., The Impact of hospitals: 300-2000 (Oxford 2007), p. 93-116; Marina Garbelloti: "Assets of the Poor, Assets of the City: The Management of Hospital Resources in Verona between the Sixteenth and Eighteenth Century", in ibid. p. 117-134.

37 StAN A 21-31 Sondersiechen-Stiftung St. Sebald auf dem Kirchhof. 
aim to cleanse the city of begging foreigners and of citizens suffering infectious diseases (in the contemporary conception) and especially lepers. But banning the charity had already failed in early $15^{\text {th }}$ century. Consequently, focusing on the foreign lepers' charity enables to detect more subtle strategies as well as their failure and thus helps to construe a more complex view on the general process.

After readmission in 1405 clerical and physical attendance to the foreign lepers was given on the churchyard of St. Sebald, one of the two big parish churches of the town. In the years 1446 to 1448 a new house had been built by the foundation for the foreign lepers with support of the municipal authorities to shelter them for three days and three nights from Tuesday afternoon until Friday afternoon in the Holy week. This could be regarded as a first isolation house that opened its doors only when needed, like the pest houses of the early $16^{\text {th }}$ century. But contrary to the latter, the house for the foreign lepers was to open and to close on fixed days of the year in the Holy Week. In the statutes of the foreign lepers' charity it is unmistakably stipulated that it should not open earlier and that everyone must leave the hospital on Good Friday. If there should be lepers who had fallen ill and were not been able to leave, they should be moved to one of the city's leprosaria. But predictably the hospital building was used for other purposes in the meantime when no foreign lepers were cared for. ${ }^{38}$ The leper-inspection was operated in another house, whose owner was asked moreover to host the horses of the foreign lepers, which were fed twice a day. Obviously one must be cautious with the notion of poverty of the foreign poor.

The part-time hospital was a big building as the charity had been a big event. The number of people coming to Nuremberg to benefit from the charity vary between several hundreds and more then 3,000: In 1462, 600 foreign lepers and several more diagnosed not to be leprous entered the city in the Holy Week, in 1574 it had been more than 3,000, 2,450 of those had been diagnosed lepers. ${ }^{39}$ This means that the number of foreign lepers in this year came close to $10 \%$ of the Nuremberg population. But already lower numbers must have caused serious fears: A Nuremberg poor law of 1478 (repeated in 1518) made coverage obligatory for every beggar afflicted by "miserable damage" in order not to horrify the urban public, especially pregnant women, by the beggar's ugly deformation..$^{40}$ Not before 1575 the City Council succeeded in relocating the event outside the city walls, to one of

38 Lochner, Die Sondersiechen in Nürnberg, p. $229 \mathrm{f}$.

39 Müllner, Die Annalen der Reichsstadt Nürnberg von 1623, vol. II, pp. 135-137.

40 "Item das auch ein yeder petler, er sey burger oder gast, dem zu petteln vergonnt wirdet, und einen offenbaren erbermlichen schaden au seinem leibe oder glidern hat, davon die swangern frawen durch gesicht schaden empfahen mochten, denselben schaden verdecken und nit offenberlich noch sichtiglich tragen noch zaigen sol, bey der puss ein jar von der stat." Almosenordnung 1478, Joseph Baader, Nürnberger Polizeiordnungen aus dem XIII. bis XV. Jahrhundert (Stuttgart 1861) p. 318. Repeated in Almosenordnung vom 22. Juni 1518, edited in Rüger, Mittelalterliches Almosenwesen, p. 72. 
the city's leprosaria. But quite clearly the charity had become very famous, so that the authorities had to publish the ordinance again in the following years shortly before the Holy Week. ${ }^{41}$

Foreign lepers probably camped outside the city walls before the gate was opened for them on Tuesday afternoon. They would then form a procession to the churchyard of St. Sebald where they were fed. On Wednesday they were inspected to ascertain that they were "unclean" and not simply simulating leprosy in order to benefit from the charity. ${ }^{42}$ An official letter signed by the examining doctor documented this examination. Those who had been found "clean" ("immundus", in the German sources "schön") were to leave the hospital but were fed the following days on the churchyard of St. Sebald. After regular confession the priest shriving the leprous handed out a distinctive sign to avoid others creeping in among the crowd of foreigners. On Thursday morning the lepers attended an open-air sermon in the churchyard on how to take the Holy Communion worthily, before taking communion inside the church. On the morning of Holy Friday, the lepers were again inspected and all were checked for written confirmation of their leprosy and proof of having been confessed before hearing a sermon on the sufferings of Christ and then eating and drinking started. Finally the lepers received clothing and some money, which was handed to them after they had given back the signs they had been given by the priest. Before leaving Nuremberg they had to promise not to come back before the following year.

This short sketch of the procedure sheds a light on the authorities' ambition to gain control. It seems that the foreign lepers were considered to be especially dangerous. Obviously, controlling the dangerous most of all meant separating them, most suitable in proper houses dedicated to that special purpose. As this was expensive, as an additional strategy the City Council tried to modify the permeability of the city gates and even special places inside the city. Changes did not simply aim at refusing the entrance of foreign beggars, but also admitting thousands of foreigners on the occasion of the presentation of the relics of the empire ("Heiltumsweisung") on the second Friday after Easter. In an ordinance of 1478 aiming to lock out foreign beggars the authorities explicitly state the exception of three days before and after this event as well as All Saints' Day and All Souls' Day in early November. ${ }^{43}$ In the same way the foreign leper's charity may be understood as an exceptional allowance, which also legitimates strict regulations.

41 Gerneth, Beitrag zur Geschichte der Lepra, pp. 74-75; Robert Herrlinger, Volcher Coiter 1534-1576 (Nürnberg 1952), p. 35.

42 Concerning the "iudicium leprosorum" cf. Demaitre, Leprosy in Premodern Medicine, p. 34-74; Rawcliffe, Leprosy in Medieval England, p. 184-190; Fritz Dross: "Vom zuverlässigen Urteilen. Ärztliche Autorität, reichsstädtische Ordnung und der Verlust armer Glieder Christi in der Nürnberger Sondersiechenschau”, in Medizin, Gesellschaft und Geschichte 29 (2010);

43 Baader, Nürnberger Polizeiordnungen, p. 318. 
In the following century the imperial city's hospital policy could be understood as a process of managing exceptions owing to exceptional circumstances. This becomes clear through the history of two foundations created by legacies of the 1480ies. ${ }^{44}$ First of all, the point that both testaments completely change the logic of the "budget for the beyond" attracts attention. Both testaments were atypical as they did not voice the desire to save their founder's souls by giving detailed and concrete instructions on how to proceed. The founders simply gave instructions to sell their property and to spent the money in God's glory ${ }^{45}$ or to serve the poor ${ }^{46}$. Both entirely relied on their executors' capability to find adequate schemes. The same person, Sebald Schreyer, executed both testaments.

Schreyer invested the assets of Georg Keipper in a foundation financing a physician, a barber-surgeon and an apothecary serving the hospital of the Holy Spirit. In the late 1480ies the hospital of the Holy Spirit became one of the first hospitals of the Empire employing and paying it's own academically trained physician. ${ }^{47}$ At the same time the City Council began planning the enlargement of the hospital of the Holy Spirit. As its location was immediately adjacent to the river Pegnitz this incurred severe technical problems. In 1488 the City Council nominated Sebald Schreyer, the executor of Keipper's last will, to be the master builder of the project which included building a bridge over the river Pegnitz.

The property of Konrad Topler, the second testator, was used by Schreyer to build a pesthouse in 1490 . Bringing the victims of pestilential epidemics into a pesthouse placed immediately outside the city walls avoided crowding the hospital of the Holy Spirit and infecting it's inmates in times of pestilence which, according to the founding charter, usually occurred every ten to twelve years in Nuremberg. ${ }^{48}$

44 Cf. Dinges, A History of Poverty and Poor Relief, p. 35f.

45 "was ich uber diese vorgeschribne mein verschickte hab und gut hiner mir lasse, ... soll man zu gelt machen, so man allererst mag und solichs gelt in Gottes ere wenden und keren..." Elisabeth Caesar, "Sebald Schreyer, ein Lebensbild aus dem vorreformatorischen Nürnberg", in Mitteilungen des Vereins für die Geschichte der Stadt Nürnberg 56 (1969), 1-213, p. 69.

46 "was ich laß [...] nichtzit hindan gesetzt, das alles sollen mein vormundt verkaufen und die kaufsumma oder dasselb gelt durch Got geben hawßarmen und andern armen leuten oder ains teils zu gotshewsern, armen clostern oder anderswo, do es notturftigklich und woll angelegt wirdet, nach iren trewen und pester verstentnus, wie si dann alle versamentlich oder durch ein merers aus in zu rat werden." Caesar, Sebald Schreyer, p. 65.

47 In southern Germany there had been no distinct hospital physicians prior to the 1480ies. See Wolfgang F. Reddig, Bürgerspital und Bischofsstadt. Das St. Katherinen- und das St. Elisabethenspital in Bamberg vom 13-18. Jahrhundert. Vergleichende Studie zu Struktur, Besitz und Wirtschaft (Bamberg 1998), p. 262. Generally, the hospitals had been served by the town physicians until early 19th century. See Fritz Dross, Krankenhaus und lokale Politik 1770-1850. Das Beispiel Düsseldorf (Essen 2004).

48 "das zu den zeiten, so auß der verhencknuß des allmechtigen Gottes durch die wurckung der cörper des himmels sich in disen landen vergiftung des luftes und regirung der pestilenz begeben, als sich dann gemainklich in zehen oder zwelf jaren ungeverlich einmal erewget in diser loblichen stat Nurmberg." Caesar, Sebald Schreyer, p. 73; Charlotte Bühl, "Die 
In the periods between pestilential epidemics, the fund's interest should be used by the Keipper-foundation for financing medical services for the hospital of the Holy Spirit. In case of plague the Keipper foundation in return was to provide medical services for the pesthouse. But already in 1493, before the foundation stone of the pesthouse had been laid down, the City Council disapproved the plan to build a separate pesthouse while enlarging the hospital of the Holy Spirit. After quitting his job as the master-builder of the enlargement of the hospital in 1491, Schreyer proceeded as protagonist of a separate pesthouse against the will of the City council. He favoured a bigger two-storeyed building while the authorities later, having decided to support the plan in the interval, wanted to build two smaller but distinguished buildings. In 1516 Schreyer finally gave up the project. ${ }^{49}$

\section{Facing the plague}

As already feared by the town authorities both projects encountered severe difficulties: The laying of the foundation stone of the pesthouse did not happen before 1497 and the wooden parts of the enlargement of the hospital of the Holy Spirit had to be demolished in 1506. More than ten years after beginning the building of the pesthouse the founding stone of its chapel was laid in 1509. The chapel grew faster than the pesthouse itself and was consecrated in 1513. The pesthouse opened before completion in 1520 but was only finished eight years later, in 1528. The following year work started again to enlarge the new pesthouse. The enlargement of the hospital of the Holy Spirit was finished by 1525. In 1552 the pesthouse was demolished for military reasons but rebuilt in the same year and again enlarged in 1592.

In a plague epidemic in $1494 / 5$ the victims had been cared for in the pilgrims' hospital of Holy Cross as well as in the hospital of the Holy Spirit. In the next year, when the so-called French Disease first struck the imperial city, the City Council accommodated its victims in the pilgrim's hospital. ${ }^{50}$ Meanwhile the City Council

Pestepidemien des ausgehenden Mittelalters und der Frühen Neuzeit in Nürnberg (1483/84 bis 1533/34)", in R. Endres, ed., Nürnberg und Bern. Zwei Reichsstädte und ihre Landgebiete (Erlangen 1990), 121-168, p. 123; Mummenhoff, Die öffentliche Gesundheits- und Krankenpflege, pp. 98-99; Müllner, Die Annalen der Reichsstadt Nürnberg von 1623, vol. III, p. $112 \mathrm{f}$.

49 Caesar, Sebald Schreyer, p. 75.

50 Mummenhoff, Die öffentliche Gesundheits- und Krankenpflege, p. 104; European reactions to the French Disease: Jon Arrizabalaga, John Henderson, Roger French: The Great Pox. The French Disease in Renaissance Europe (New Haven 1997); Annemarie Kinzelbach: "“Böse Blattern" oder "Franzosenkrankheit": Syphiliskonzept, Kranke und die Genese des Krankenhauses in oberdeutschen Reichsstädten in der frühen Neuzeit", in M. Dinges, Th. Schlich, eds., Neue Wege in der Seuchengeschichte (Stuttgart 1995), p. 43-70; Claudia Stein: "The 
tried to isolate people suffering from French Disease in tiny barracks and in 1507 opened a small pox-house; in 1523 he decided to build a new and bigger one. In the years 1514, 1515 and 1517 the new buildings of the hospital were near completion but still not in regular use, when at the same time 250 people were reported in the hospital which was clearly overcrowded. Moreover, during the Holy Week the hospital of the Holy Spirit was reported to shelter up to 700 lepers. ${ }^{51}$ If this is not a mistake by the chronicler Sebastian Müllner of the $17^{\text {th }}$ century, which is possible but not most likely, this means that when the hospital of the foreign lepers was overcrowded by approximately $600-800$ people, everyone beyond that number was hosted in the hospital of the Holy Spirit. While the big hospital of the Holy Spirit and the pilgrims' hospitals are frequently mentioned as provisional accommodation for the sick in case of need, there is no evidence that the hospital of the foreign lepers ever was used that way although it was filled only three days a year. In 1525 yet the scales for flour were moved from the "Sondersiechenhaus" to a chapel near the hospital of the Holy Spirit for their location had been deemed inconvenient. $^{52}$

Already when opened before completion in 1520 the pesthouse broke the instructions of its foundation charter. This document intended the pesthouse to host the convalescent for three more weeks and to accommodate both for Nuremberg citizens and the inhabitants of surrounding villages, but the City Council instructed the hospital master to discharge everyone no longer seriously ill and not to admit foreigners. ${ }^{53}$ According to its dedication the pesthouse was opened in times of plague. But there were several exceptions like in 1523 when the City Council decided to erect a new pox-house and brought the people suffering from French Disease from the older pox-house, which was described as overcrowded, into the pesthouse still under construction. ${ }^{54}$

The opening of the pesthouse was a widely recognised indication that the situation was out of control and in the later $16^{\text {th }}$ century the City Council usually opened the pesthouse when the reality of the plague epidemic could no longer be kept from the inhabitants and the town's commercial partners elsewhere. ${ }^{55}$ At the same time only a smaller part of the infected were forced to move into the pesthouse. In the epidemic of 1533 , for example, according to some sources quoted by the chronicler Müllner, 1,100 people died in the pesthouse while 5,830 died in

Meaning of Signs: Diagnosing the French Pox in Early Modern Augsburg", in Bulletin of the History of Medicine 80 ( 2006), p. 617-648.

51 Müllner, Die Annalen der Reichsstadt Nürnberg von 1623, vol. III, p. 437.

52 "weil sie daselbs etwas ungelegen gewest" Müllner, Die Annalen der Reichsstadt Nürnberg von 1623, vol. III, p. 564.

53 Bühl, Die Pestepidemien des ausgehenden Mittelalters, p. 150.

54 Mummenhoff, Die öffentliche Gesundheits- und Krankenpflege, p. 105

55 Carolin Porzelt, Die Pest in Nürnberg. Leben und Herrschen in Pestzeiten in der Reichsstadt Nürnberg (1562-1713) (St. Ottilien 2000). 
town. ${ }^{56}$ In early September that year there were 250 people inside the pesthouse increasing to 490 within nearly three weeks. When in 1542 an epidemic was declared among thousands of mercenaries around Nuremberg and led to many soldiers dying on the streets ${ }^{57}$ the City Council opened the hospital of the Holy Spirit. After the hospital had been overcrowded he also opened the pesthouse to the sick soldiers. ${ }^{58}$ In the following year the pesthouse was opened because of plague but in 1544 it did not open during an epidemic because "only the poor have died". ${ }^{59}$ This could possibly be linked to different states of contagiousness. Physicians in the imperial town of Nördlingen (about 100 kilometres south-western from Nuremberg) in 1571 distinguished two different classes of pestilence. ${ }^{60}$ Secondary to the very contagious and dangerous form they described another one caused namely by malnutrition. The latter hardly affected the wealthier.

\section{Beyond the plague}

Confronted with plague and epidemics early modern hospital policies do not appear to have been very successful. The detailed picture of founding new hospitals, enlarging the older ones, re-building and re-dedicating several others is confusing, indeed. But one has to realise that what has been looked at in the last paragraph mostly have been bustling activities in times of a social, economical and political catastrophe. In modern times when activities of administrative units on nearly every level produce documents and records, as historians one has to be cautious not to overestimate the sheer number of sources produced on such very special occasions. Not to have that amount of sources in between epidemics must be interpreted by the assumption that the main concepts were not challenged and worked in a way satisfying the persons in charge.

At the same time a new paradigm emerges. Reacting to special needs in public health affairs usually meant some kind of building activity or, more precisely, the preparation of building activity. The authorities began confronted to a special sanitary necessity, at least since mid- $15^{\text {th }}$ century, preparing the erection of a special building. This sounds banal and insignificant as it is the very condition for any

56 Müllner, Die Annalen der Reichsstadt Nürnberg von 1623, vol. III, p. 642.

57 "die arme Knecht hin und her an den Strassen gestorben", Müllner, Die Annalen der Reichsstadt Nürnberg von 1623, vol. III, p. $708 \mathrm{f}$.

58 Müllner, Die Annalen der Reichsstadt Nürnberg von 1623, vol. III, p. 708f; Ulrich Knefelkamp: "Über die Pflege und medizinische Behandlung von Kranken in Spitälern vom 14. bis 16. Jahrhundert", in M. Matheus, ed., Funktions- und Strukturwandel spätmittelalterlicher Hospitäler im europäischen Vergleich (Stuttgart 2005), p186.

59 "Sein aber nur viel arme Leut gestorben" Müllner, Die Annalen der Reichsstadt Nürnberg von 1623, vol. III, p. 740.

60 Kinzelbach, Infection, Contagion, and Public Health, p. 383. 
hospital policy. Furthermore the hospitals and hospital-like buildings considered here were dedicated to distinguished types of care, of different groups of people to be cared for and different caregivers. Concerning the sources one must conclude that they themselves were destined to help gaining control in case of panic. They do not tell the every-day standard of caregiving but report the exceptional case, e.g. when hundreds of foreign lepers were sheltered in the hospital of the Holy Spirit and people suffering the French Disease were sent to the pilgrims' hospital of Holy Cross. Within these exceptions in times of epidemics one could detect that the biggest of the Nuremberg hospitals, the hospital of the Holy Spirit, most of all was used in an exceptional way. If a bigger group of people unexpectedly needed to be hosted, the City Council first of all tried to accommodate them in the hospital of the Holy Spirit. Secondary the authorities sought to shelter them in the two pilgrim's hospitals. Thirdly they opened the pesthouse. At the same time, there was a big (and empty) building, the foreign lepers' charity, which could hold up to 800 individuals in the Holy Week ("Sondersiechenhaus"). Both the "Sondersiechenhaus" and the four leprosaria outside the city walls were not used to shelter others than (foreign) lepers in the period under discussion.

Within this subsidiary structure the hospital of the Holy Spirit acted as a container in cases of urgent needs. But this was definitely not what it was meant to be its place within the Nuremberg landscape of hospitals. In fact, it was quite the opposite: having a fully equipped medical branch of its own, it was to become the city's medical care centre. Hospital statutes of 1565 do not only very clearly describe the admission procedure, but also the way in which and when the inmates should be released from hospital. ${ }^{61}$ In case of need an ill person should send his spouse or someone to the hospital and announce his misery and sickness. By the way within this formulation once again we find the notion of sickness as an inability to get up and move mentioned above. The hospital master then should assign the probingwomen ("Schauerin") to visit the person announced and to examine if she or he was entitled to be admitted within the hospital. The sick person should only be kept until her or his recovery. With respect to discharging the inmates the probingwoman ought to visit the wards routinely once a week in order to explore which of the inmates had recovered and could be released. When discharged, patients would receive some bread and some money to help them on their way home. No one should be discharged because of favour or by accepting a gift.

Remarkably, although employing a physician, a barber-surgeon as well as an apothecary, the decision to admit and to discharge persons was made by a female professional. ${ }^{62}$ For my purpose here, I would like to highlight the detailed regulations concerning the discharge of recovered hospital inmates. Relying on detailed

61 Knefelkamp, Das Heilig-Geist-Spital in Nürnberg, p. $197 f$.

62 The official oath of the "Schauerin" in Knefelkamp, Das Heilig-Geist-Spital in Nürnberg, p. 386. 
data concerning late $16^{\text {th }}$ and early $17^{\text {th }}$ century Ulrich Knefelkamp has already shown that most of the inmates of the hospital of the Holy Spirit left the hospital after a stay of three or four weeks and that nearly a third left the hospital even earlier. ${ }^{63}$ The general patterns resemble those found by Uta Lindgren when working on Barcelona's hospitals between 1480-1500. ${ }^{64}$ This could only be achieved by an already highly differentiated landscape of hospitals, structured in a subsidiary way in $16^{\text {th }}$ century Nuremberg.

\section{Conclusion}

It may be the case that historians of the early modern hospitals are too partial in focusing on the admission rules and the entrance barriers of hospitals. These serve as indicators of a certain degree of specialisation already in the Renaissance and early modern hospital. But specialisation in the Renaissance hospital must not be interpreted as a specialisation based upon our modern criteria. At the same time one could search for the complementary regulations of dismissal in a subsidiary structure of hospitals distinguishing different groups of people to be cared for and applying different ways of taking care. Not focusing on the success or failure of medical therapy alone would widen the perspective to several kinds of in-house care given temporarily. The inmates' condition to be released could be achieved by several ways among which medical therapy is only one - although growing in the following centuries. Finally discharging people from hospitals radically changed the logic of charitable hospitalisation. Caring for others started to become a commercial branch, when neighbours of a Nuremberg woman in 1544 accused her of accommodating sick persons and the City Council granted her engagement because no one could be forced to send her or his kin members into hospital. ${ }^{65}$ By getting rid of their inmates as fast as possible hospitals could care for more people actually in need. Thus at least the figure of the hospital master in the $17^{\text {th }}$ story of Till Eulenspiegel finds a clearer explanation.

Fritz Dross is assistant professor at the Institute for History of Medicine and Medical Ethics, Friedrich-Alexander-Universität Erlangen-Nürnberg, Germany.

63 Knefelkamp, Das Heilig-Geist-Spital in Nürnberg, p. 276-331. Likewise, John Henderson stated facing the Florentine hospitals in 14th and 15th centuries, that people came into the hospitals not in order to die but to leave the hospital cured and living as fast as possible. Henderson, Medizin für den Körper und Medizin für die Seele, p. 32.

64 Uta Lindgren, Bedürftigkeit, Armut, Not. Studien zur spätmittelalterlichen Sozialgeschichte Barcelonas (Münster 1980).

65 Knefelkamp, Das Heilig-Geist-Spital in Nürnberg, p. 197. 


\section{References}

Abreu, L., "Beggars, Vagrants and Romanies: Repression and Persecution in Portuguese Society (14th-18th Centuries)" in Hygiea Internationalis 6(1), (2007), 41-66.

Arrizabalaga, J., J. Henderson, Kenneth French, R., The Great Pox. The French Disease in Renaissance Europe (New Haven, Yale University Press 1997).

Baader,J., Nürnberger Polizeiordnungen aus dem XIII. bis XV. Jahrhundert (Stuttgart, Literarischer Verein 1861).

Buchloh, J., Hans Baldung Grien und Dyl Ulenspiegel. Studien zu den Illustrationen und zur Text-Bild-Struktur des Straßburger Eulenspiegeldruckes S 1515 (Berlin 2005), (Diss. phil. TU Berlin), <http://deposit.ddb.de/cgi-bin/dokserv? idn=976609576> 15/07/2010, english translation: <http://ufdcweb1. uflib.ufl.edu/ufdc/?m=hd54J\&i=56821 > 15/07/2010.

Bühl, C., "Die Pestepidemien des ausgehenden Mittelalters und der Frühen Neuzeit in Nürnberg (1483/84 bis 1533/34)" in Rudolf Endres (ed.), Nürnberg und Bern. Zwei Reichsstädte und ihre Landgebiete (Erlangen 1990), pp. 121168.

Caesar, E., "Sebald Schreyer, ein Lebensbild aus dem vorreformatorischen Nürnberg" in Mitteilungen des Vereins für die Geschichte der Stadt Nürnberg ,56 (1969), 1-213.

Demaitre, L. E., Leprosy in premodern medicine. A malady of the whole body (Baltimore, Johns Hopkins University Press 2007).

Diefenbacher, M., Das älteste Urbar des Nürnberger Heilig-Geist-Spitals, (ed.), v. Stadtarchiv Nürnberg. bearb. von Michael Diefenbacher (Nürnberg 1991),

Diefenbacher, M., Sechshundertfünfzig 650 Jahre Hospital zum Heiligen Geist in Nürnberg: 1339-1989 (Nürnberg 1989), (Ausstellung d. Stadtarchivs Nürnberg 9. Nov. - 1. Dez. 1989).

Dinges. M., "A History of Poverty and Poor Relief: Contributions from Research on the Early Modern Period and the Late Middle Ages and Examples from More Recent History" in Laurinda Abreu, (ed.), European health and social welfare policies, (Santiago de Compostela, Compostela Group of Universities [u.a.] 2004), pp. 23-50.

Dinges, M., "Introduction to the Volume: Situating Health Care: An Historical Perspective" in Hygiea Internationalis 5(1) (2005), 7-13.

Dross, F., Krankenhaus und lokale Politik 1770-1850. Das Beispiel Düsseldorf (Essen, Klartext 2004), (Düsseldorfer Schriften zur Neueren Landesgeschichte und zur Geschichte Nordrhein-Westfalens 67).

Dross, F., "The Invention of a Medical Institution? A Discussion of Hospitals around 1800" in Hygiea Internationalis 5(1) (2005), 91-106. 
Dross, F., "Vom zuverlässigen Urteilen. Ärztliche Autorität, reichsstädtische Ordnung und der Verlust armer Glieder Christi in der Nürnberger Sondersiechenschau" in Medizin, Gesellschaft und Geschichte 29 (2010) (to appear in print 2011).

Dücker, K., Literarische Bösewichte des (Spät)mittelalters und ihre mögliche Vorbildfunktion für das Eulenspiegelbuch (Tampere 2007) (Pro Gradu-Arbeit, Institut für Sprach- und Translationswissenschaften, Deutsche Sprache und Kultur, Universität Tampere), <http://tutkielmat.uta.fi/pdf/gradu01649.pdf> 15/07/2010.

Garbelloti, M., "Assets of the Poor, Assets of the City: The Management of Hospital Resources in Verona between the Sixteenth and Eighteenth Century" in Henderson, P. Horden, A. Pastore, (eds.), The Impact of hospitals: 300-2000 (Oxford, Lang 2007), pp. 117-134.

Gerneth, G., Beitrag zur Geschichte der Lepra und Leproserien in der alten Reichsstadt Nürnberg und in Fürth (Erlangen 1949) (Diss. med. Erlangen).

Grünsteudel, G., (ed.), Augsburger Stadtlexikon (Augsburg, Perlach-Verl 2., völlig neu bearb. und erheblich erw. Aufl. 1998).

von Hallerstein, H. H. and E. Eichhorn (Kunsthistoriker), Das Pilgrimspital zum Heiligen Kreuz vor Nürnberg. Geschichte und Kunstdenkmäler (Nürnberg, Verein für Geschichte der Stadt Nürnberg 1969).

Henderson, J., "Medizin für den Körper und Medizin für die Seele - Hospitäler im Florenz der Renaissance" in M. Matheus (ed.), Funktions- und Strukturwandel spätmittelalterlicher Hospitäler im europäischen Vergleich [8. Alzeyer Kolloquium, 1999] (Stuttgart, Steiner 2005), pp. 29-58.

Herrlinger, R., Volcher Coiter 1534-1576 (Nürnberg, Edelmann 1952).

Jankrift, K. P., "Hospitäler und Leprosorien im Nordwesten des mittelalterlichen Regnum Teutonicum unter besonderer Berücksichtigung rheinischwestfälischer Städte" M. Scheutz, A. Sommerlechner, H. Weigl and A. Stefan Weiß (eds.), Europäisches Spitalwesen - Institutionelle Fürsorge in Mittelalter und Früher Neuzeit, Wien (München, Oldenbourg 2008), pp. 295-306.

Jütte, R., Obrigkeitliche Armenfürsorge in deutschen Reichsstädten der frühen Neuzeit. Städtisches Armenwesen in Frankfurt am Main und Köln (Köln, Böhlau 1984) (Kölner historische Abhandlungen 31).

Kinzelbach, A., Gesundbleiben, Krankwerden, Armsein in der frühneuzeitlichen Gesellschaft. Gesunde und Kranke in den Reichsstädten Überlingen und Ulm, 1500-1700 (Stuttgart, Steiner 1995) (Medizin, Gesellschaft und Geschichte, Beiheft 8).

Kinzelbach, A., “Böse Blattern' oder „Franzosenkrankheit: Syphiliskonzept, Kranke und die Genese des Krankenhauses in oberdeutschen Reichsstädten in der frühen Neuzeit" in M. Dinges and T. Schlich (eds.), Neue Wege in der Seuchengeschichte (Stuttgart, Steiner 1995), pp. 43-70. 
Kinzelbach A., "Infection, Contagion, and Public Health in Late Medieval and Early Modern German Imperial Towns" in Journal of the History of Medicine and Allied Sciences 61(3) (2006), 369-389.

Knefelkamp U., Das Heilig-Geist-Spital in Nürnberg vom 14.-17. Jahrhundert: Geschichte, Struktur, Alltag (Nürnberg, Selbstverl. des Vereins für Geschichte der Stadt Nürnberg 1989) (Nürnberger Forschungen 26).

Knefelkamp, U., "Stadt und Spital im späten Mittelalter. Ein struktureller Überblick zu Bürgerspitälern süddeutscher Städte" in P. Johanek (ed.), Städtisches Gesundheits- und Fürsorgewesen vor 1800 (Köln, Weimar Wien, Böhlau 2000), pp. 19-40.

Knefelkamp, U., "Über die Pflege und medizinische Behandlung von Kranken in Spitälern vom 14. bis 16. Jahrhundert" in Michael Matheus (ed.), Funktionsund Strukturwandel spätmittelalterlicher Hospitäler im europäischen Vergleich [8. Alzeyer Kolloquium, 1999] (Stuttgart, Steiner 2005), pp. 175-194.

Lindgren, U., Bedürftigkeit, Armut, Not. Studien zur spätmittelalterlichen Sozialgeschichte Barcelonas (Münster (Westf.), Aschendorffsche Verlagsbuchhandlung 1980).

Lindow, W., (ed.), Ein kurtzweilig Lesen von Dil Ulenspiegel, geboren uß dem Land zu Brunßwick. Wie er sein Leben volbracht hatt. 96 seiner Geschichten. Nach dem Druck von 1515 (Stuttgart, Reclam 1978), <http://www.zeno.org/Literatur/ M/Bote, + Hermann/Schwanksammlung/Dil+Ulenspiegel> 15/07/2010.

Lochner, G. W. K., "Die Sondersiechen in Nürnberg, ihr Almosen und ihre Schau" in Deutsche Zeitschrift für die Staatsarzneikunde NF 17 (1861), Nr. IV, 177252.

Löhlein G., "Die Gründungsurkunde des Nürnberger Heilig-Geistspitals von 1339" in Mitteilungen des Vereins für die Geschichte der Stadt Nürnberg 52 (1963/64), 65-79.

Mackenzie, K. R. H. Master Tyll Owlglass: His Marvellous Adventures and Rare Conceits (London 1859).

Müllner, H., Die Annalen der Reichsstadt Nürnberg von 1623. III: 1470 bis 1544, (ed.), v. unter Mitw. von Walter Gebhardt bearb. von Michael Diefenbacher, Nürnberg 2003.)

Müllner, J., Die Annalen der Reichsstadt Nürnberg von 1623. II: 1351 bis 1469, (ed.), v. Gerhard Hirschmann (Nürnberg 1984) (mit einer Einleitung (ed.), v. Gerhard Hirschmann).

Mummenhoff, E., Die öffentliche Gesundheits- und Krankenpflege im alten Nürnberg, Neustadt an d. Aisch 1986 (Unveränd. Nachdr. aus: FS zur Eröffnung des neuen Krankenhauses der Stadt Nürnberg 1898), <http://www.nuernbergerhausbuecher.de/> 15/07/2010. 
Pilz, K., Die Evangelisch-Reformierte St.-Marthakirche und das Pilgrim-Spital St. Martha. Die reformierte Gemeinde in Nürnberg (Nürnberg, Evang.Reformiertes Pfarramt 1979).

Poeck, D. W., "Wohltat und Legitimation" in P. Johanek (ed.), Städtisches Gesundheits- und Fürsorgewesen vor 1800 (Köln, Weimar, Wien, Böhlau 2000), pp. 1-17.

Pohl-Resl, B., Rechnen mit der Ewigkeit. Das Wiener Bürgerspital im Mittelalter (Wien, München, Oldenbourg 1996).

Porzelt C., Die Pest in Nürnberg. Leben und Herrschen in Pestzeiten in der Reichsstadt Nürnberg (1562K1713) (St. Ottilien, EOS-Verl. Erzabtei St. Ottilien 2000) (Forschungen zur Landes- und Regionalgeschichte 7).

Rawcliffe C., Leprosy in Medieval England (Woodbridge, Boydell Press 2006).

Rawcliffe C., "'A Word from Our Sponsor': Advertising the Patron in the Medieval Hospital" in J. Henderson, P. Horden, A. Pastore, (eds.), The Impact of hospitals: 300-2000 (Oxford, Lang 2007), pp. 167-194.

Reddig, W. F., Bürgerspital und Bischofsstadt. Das St. Katherinen- und das St. Elisabethenspital in Bamberg vom 13. - 18. Jahrhundert. Vergleichende Studie zu Struktur, Besitz und Wirtschaft (Bamberg [u.a.], Scrîpvaz-Verl. 1998) (Spektrum Kulturwissenschaften 2).

Resl, B., "Hospitals in Mediaeval England" in M. Scheutz, A. Sommerlechner, H. Weigl, A. S. Weiß (eds.), Europäisches Spitalwesen - Institutionelle Fürsorge in Mittelalter und Früher Neuzeit (Wien, Münchenm Oldenbourg 2008), pp. 4152.

Riha, O., “krank und siech' Zur Geschichte des Krankheitsbegriffs" in A. Friedrich, C. Vanja and F. Heinrich (eds.), Das Hospital am Beginn der Neuzeit. Soziale Reform in Hessen im Spiegel europäischer Kulturgeschichte (Petersberg, Michael Imhof Verlag 2004), pp. 191-201.

Rosseaux, U., Städte in der Frühen Neuzeit (Darmstadt, Wiss. Buchges. 2006), $<$ http://www.augsburger-stadtlexikon.de/index.php > 15/07/2010.

Rüger, W., Mittelalterliches Almosenwesen: Die Almosenordnungen der Reichsstadt Nürnberg (Nürnberg, Krische 1932).

Seidel, C., Die Siechköbel vor den Mauern Nürnbergs (Erlangen 1984) (Magisterarbeit FAU Erlangen-Nürnberg).

Sneider, M. T., "The Treasury of the Poor: Hospital Finance in Sixteenth and Seventeenth-Century Bologna" in Henderson, P. Horden, A. Pastore, (eds.), (Oxford, Lang 2007), pp. 93-116.

Stein, C., "The Meaning of Signs: Diagnosing the French Pox in Early Modern Augsburg" in Bulletin of the History of Medicine 80(4) (2006), pp. 617-648.

Steinmaier, W., St. Jobst. Das Aussätzigenspital am Empfangsweg des Kaisers. Herrscherkult und Siechenhaus, ein Beitrag zum Stadtausbau unter Karl IV. und zum Spitalwesen der freien Reichsstadt Nürnberg (Nürnberg, Mabase 2006). 
Tabuteau, B., "Historical Research Developments on Leprosy in France and Western Europe" in B. S. Bowers (ed.), The medieval hospital and medical practice (Aldershot, Ashgate 2007), pp. 41-58.

Tenberg R., Die deutsche Till-Eulenspiegel-Rezeption bis zum Ende des 16. Jahrhunderts (Würzburg, Königshausen \& Neumann 1996). 